\title{
Annotated genome sequences of the carnivorous plant Roridula gorgonias and a non-carnivorous relative, Clethra arborea
}

\author{
Stefanie Hartmann ${ }^{*}$ (D, Michaela Preick${ }^{1}$, Silke Abelt ${ }^{1}$, André Scheffel ${ }^{2}$ and Michael Hofreiter ${ }^{1}$
}

\begin{abstract}
Objective: Plant carnivory is distributed across the tree of life and has evolved at least six times independently, but sequenced and annotated nuclear genomes of carnivorous plants are currently lacking. We have sequenced and structurally annotated the nuclear genome of the carnivorous Roridula gorgonias and that of a non-carnivorous relative, Madeira's lily-of-the-valley-tree, Clethra arborea, both within the Ericales. This data adds an important resource to study the evolutionary genetics of plant carnivory across angiosperm lineages and also for functional and systematic aspects of plants within the Ericales.
\end{abstract}

Results: Our assemblies have total lengths of $284 \mathrm{Mbp}$ (R. gorgonias) and $511 \mathrm{Mbp}$ (C. arborea) and show high BUSCO scores of $84.2 \%$ and $89.5 \%$, respectively. We used their predicted genes together with publicly available data from other Ericales' genomes and transcriptomes to assemble a phylogenomic data set for the inference of a species tree. However, groups of orthologs showed a marked absence of species represented by a transcriptome. We discuss possible reasons and caution against combining predicted genes from genome- and transriptome-based assemblies.

Keywords: Carnivorous plant, Roridula gorgonias, Clethra arborea, Genome assembly, Transcriptome assembly, Phylogenomics, Orthologous Matrix (OMA) Project

\section{Introduction}

Although plants can convert water, $\mathrm{CO}_{2}$, and light energy into organic compounds by photosynthesis, they require additional minerals and nutrients for growth and reproduction. Most plants take up these essential compounds from the soil. Several plants in multiple and diverse angiosperm lineages, however, have independently adopted a carnivorous life style [1]: they attract and capture insect prey and absorb essential nutrients from the dead animals. Not surprisingly, plant carnivory has evolved mostly in areas that are low in nutrients, so the increased nutrient availability through predation provides a clear selective advantage.

\footnotetext{
*Correspondence: stefanie.hartmann@uni-potsdam.de

${ }^{1}$ Institute for Biochemistry and Biology, University of Potsdam,

Karl-Liebknecht-Str. 24-25, 14476 Potsdam, Germany
}

Full list of author information is available at the end of the article
To study the evolution and molecular adaptations involving plant carnivory, annotated genome data is an essential resource. However, although more than 600 carnivorous plant species have been described [1], sequenced and annotated nuclear genomes of only four of these remarkable plants are currently available [2-5]. For a few additional carnivorous plants, unannotated genome [6] or transcriptome assemblies [7-10] are available. Sequence data for molecular and evolutionary studies in carnivorous plants is therefore clearly lacking. This study contributes the nuclear genomes of two plants within the Ericales: of the carnivorous plant Roridula gorgonias, considered by some authors as proto-carnivorous [11], as well as that of a non-carnivorous relative, Madeira's lily-of-the-valley-tree, Clethra arborea. We have used the predicted genes of their genomes for a phylogenomic analysis of plants within the Ericales and conclude that

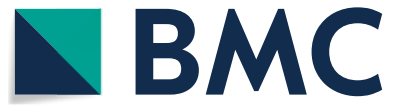

(c) The Author(s) 2020. This article is licensed under a Creative Commons Attribution 4.0 International License, which permits use, sharing, adaptation, distribution and reproduction in any medium or format, as long as you give appropriate credit to the original author(s) and the source, provide a link to the Creative Commons licence, and indicate if changes were made. The images or other third party material in this article are included in the article's Creative Commons licence, unless indicated otherwise in a credit line to the material. If material is not included in the article's Creative Commons licence and your intended use is not permitted by statutory regulation or exceeds the permitted use, you will need to obtain permission directly from the copyright holder. To view a copy of this licence, visit http://creativeco mmons.org/licenses/by/4.0/. The Creative Commons Public Domain Dedication waiver (http://creativecommons.org/publicdomain/ zero/1.0/) applies to the data made available in this article, unless otherwise stated in a credit line to the data. 
genome-based protein sets, as opposed to incomplete and fragmented transcriptome-based data, are needed for future phylogenomic studies that focus on systematic and functional aspects of this plant group.

\section{Main text}

Materials and methods

Sample collection

Clethra arborea Aiton leaves (IPEN number PT0-B-3250100; source: Madeira, Funchal) were sampled at the Botanical Garden in Berlin on Oct 22, 2018 for estimation of genome size and on Apr 1, 2019 for DNA extraction and sequencing. Roridula gorgonias Planch. (IPEN number XX-0-B-0981111; source: Botanical Garden Liberec) was sampled at the Botanical Garden in Berlin on Apr 1, 2019 for DNA extraction and sequencing; leaves were sticky but free of macroscopic insect remains. C. arborea leaves for estimation of genome size were kept wrapped in moist paper towels at 4 degrees Celsius until use the next day; young leaves for DNA extraction from both species were separately collected into and stored in liquid Nitrogen until use.

\section{Estimation of C. arborea genome size}

The genome size of $R$. gorgonias was reported to be 186 Mbp [12]. For C. arborea, no information about genome size was available, although the plant is known to be diploid with two sets of eight chromosomes [13]. Prior to sequencing, we determined nuclear DNA content of $C$. arborea by flow cytometry using the FACSAria II cell sorter (BD Bioscience). Nuclei suspensions were prepared using Otto buffers [14], supplemented with $50 \mu \mathrm{g} /$ $\mathrm{ml}$ of RNase A solution and $50 \mu \mathrm{g} / \mathrm{ml}$ propidium iodide solution. Fluorescence was measured using a blue laser (488 nm), a 616/23 nm band-pass filter, and a $610 \mathrm{LP}$ mirror. Based on the ratio between the mean value for the $8 \mathrm{C}$ peak of the internal standard Arabidopsis thaliana Col- 0 and the mean value of the $2 \mathrm{C}$ sample peak, the haploid genome size of $C$. arborea was estimated to be $550 \mathrm{Mbp}$.

\section{DNA isolation, $10 \times$ library preparation, and sequencing}

Plant leaves were ground in liquid Nitrogen, and $51 \mathrm{mg}$ powder from $C$. arborea and $56 \mathrm{mg}$ from $R$. gorgonias were used for DNA extraction with the Power Plant Pro Kit (Qiagen); the Phenolic Separation Solution was used for extraction, and a vortexing step was used after RNA digestion. Tape Station results showed a peak of 20,504 bp for R. gorgonias and 27,474 bp for C. arborea.

Libraries were prepared with the Genome Protocol Kit from the Genome Reagent Kits (10x Chromium) and were quantified using the NEBNext Library Quant Kit (New England Biolabs). They had DNA concentrations of
$1.78 \mathrm{nM}$ (C. arborea) and $4.2 \mathrm{nM}$ ( $R$. gorgonias). Libraries were sequenced on an Illumina NextSeq 500 platform using $2 \times 150 \mathrm{bp}$ paired-end sequencing; this resulted in $537 \mathrm{M}$ (C. arborea) and 177M (R. gorgonias) reads.

\section{Genome assembly}

The Supernova software $(10 \times$ Genomics) was used to extract fastq files and generate de novo assemblies. For the assemblies, data was subsampled to $350 \mathrm{M}$ reads for $C$. arborea and to $115 \mathrm{M}$ reads for $R$. gorgonias. Scaffolds of at least 1,000 bp were output using the Supernova pseudohap style, which represents an arbitrary mix of maternal and paternal alleles.

\section{Identification and removal of contamination}

Assemblies were compared to a custom database of reference genomes available from NCBI. For this analysis, only complete genomes were retrieved for bacteria, while no such restriction was used for the other divisions. This resulted in a dataset comprising 886 genomes from archaea, 293 from bacteria, 188 from invertebrates, and 94 from protozoa. As an alternative database, a local installation of Genbank's nt (v.230) was used. The software BLAST $[15,16]$ was used to separately compare $C$. arborea and $R$. gorgonias scaffolds to these two databases with an E-value threshold of $10^{-15}$ and a maximum of 10 target sequences. The resulting tables were imported into MEGAN6-LR [17], and scaffolds were read in as long-reads.

\section{Genome annotation using MAKER}

RepeatModeler (http://www.repeatmasker.org/RepeatModeler/) was used to identify species-specific repeats for $R$. gorgonias and $C$. arborea. The resulting libraries of repeats were used for the subsequent genome annotation steps. For structural genome annotation, MAKER [18] was run iteratively: during the first round, 42,988 predicted protein sequences from Actinidia chinensis [19], 34,015 from Actinidia eriantha [20], and 42,509 UniProt [21] sequences from plants (sprot division only) were used as evidence for homology-based gene prediction. Results from this first run were used to train SNAP HMMs. These, as well as Augustus HMMs from a BUSCO run on the assembled scaffolds were used for a second round of gene predictions. Results were used to re-train SNAP and Augustus HMMs, and these were used for a third and final round of gene predictions.

\section{Gene family estimation and analysis}

To assign the predicted proteins of $C$. arborea and $R$. gorgonias to orthologous gene families of other Ericales' genomes for which predicted proteins were available, the algorithm of the OMA (Orthologous MAtrix) project 
[22] was used. Genome- and transcriptome- based studies we included are listed in Table 1 . Protein predictions from genome assemblies were directly used. For four transcriptome data sets, TransDecoder [23] was used to identify the single best open reading frame per transcript, resulting in the total numbers of predicted proteins given in Table 1. For Diospyros lotus, however, this resulted in 219,698 predicted proteins, which clearly is an overestimation and would have had to be filtered. Therefore, this species was excluded from our analysis. For other sequenced plant genomes and transcriptomes within the Ericales, such as Argania spinosa [24], Monotropa hypopitys [25], and Embelia ribes (unpublished; direct submission of contigs), no predicted proteins were available for download, and these species were therefore also excluded. As outgroup for phylogenetic analyses, we included 44,655 predicted proteins of Daucus carota [26].

These protein sequences were used as input for the standalone OMA pipeline [27], and a total of 63,256 gene sets for which all pairs are inferred to be orthologs ("OMA groups") were generated. The OMA algorithm computes high-quality orthologs but tends to output more and smaller gene families than other approaches [27]. This was also observed here, with $72.5 \%$ of the OMA groups containing sequences of five or fewer species. For further analysis we selected the 4,901 groups that contained representatives of at least 7 of the 10 ingroup species and also included a Daucus carota sequence. For each of the 2434 OMA groups in which all genome-based species were present (see below), we computed a multiple sequence alignment using MAFFT v7.455 [28] and a Maximum Likelihood phylogeny using RAxML v8.2.12 [29] using the PROTGAMMAWAG model and the $D$. carota sequence as outgroup.

\section{Results and discussion}

We sequenced and assembled the nuclear genomes of the carnivorous plant $R$. gorgonias and the non-carnivorous $C$. arborea. Summary and quality metrics of the final assemblies were generated using quast [30] and are shown in Table 2.

\section{Identification and removal of contamination}

No scaffolds from $C$. arborea were assigned to any of the non-plant lineages. For $R$. gorgonias, the same six scaffolds were assigned to insects with both databases, and four additional scaffolds were assigned to insects using the custom database. These ten $R$. gorgonias scaffolds ranged in size from $1.3 \mathrm{kbp}$ to $45.3 \mathrm{kbp}$ and were assigned to Neoptera, Holometabola, Diptera, or Schizophora using the custom database. They had a cumulative length of $92.5 \mathrm{kbp}$ and were removed from the assembly for subsequent analyses. The resulting $R$. gorgonias assembly is approximately $100 \mathrm{Mbp}$ larger than an estimation based on Feulgen microdensitometry [12].

\section{Genome annotation using MAKER}

The final set of predicted genes using MAKER consisted of 31,129 genes for C. arborea and 22,655 for R. gorgonias. The BUSCO software [31] was used to evaluate completeness of the two annotations. Of 2,121 near universal single copy orthologs of eudicots (datasets based on OrthoDB release 10), $89.5 \%$ were identified for $C$. arborea and $84.2 \%$ for $R$. gorgonias. Full BUSCO statistics are provided in Table 2 .

\section{Evaluation of gene families}

Using as input the predicted genes from $R$. gorgonias and $C$. arborea, together with public protein sets from

Table 1 Summary statistics for gene total numbers and lengths of the full data sets used for the inference of gene families

\begin{tabular}{|c|c|c|c|c|c|c|c|}
\hline & Min & Median & 3rd Qu & Max & Total & Type & Reference \\
\hline A. chinensis & 4 & 353 & 535 & 5453 & 34,015 & g & [19] \\
\hline A. eriantha & 2 & 268 & 438 & 5498 & 42,988 & g & [20] \\
\hline C. arborea & 14 & 324 & 520 & 4973 & 31,129 & g & This study \\
\hline Ca. sinensis & 29 & 325 & 515 & 5786 & 76,698 & g & [33] \\
\hline D. carota & 29 & 399 & 601 & 5453 & 44,655 & g & [26] \\
\hline P. veris & 23 & 366 & 544 & 4732 & 18,301 & $g$ & [34] \\
\hline P. vulgaris & 49 & 375 & 605 & 5347 & 28,441 & g & [35] \\
\hline R. gorgonias & 21 & 325 & 509 & 5314 & 22,655 & g & This study \\
\hline S.psittacina & 39 & 108 & 155 & 447 & 22,690 & $t$ & [7] \\
\hline S.purpurea & 41 & 111 & 158 & 831 & 18,748 & $\mathrm{t}$ & [7] \\
\hline V.macrocarpon & 40 & 118 & 212 & 2061 & 34,789 & $\mathrm{t}$ & [36] \\
\hline Di. lotus & 40 & 74 & 107 & 4354 & 219,698 & $\mathrm{t}$ & [37] \\
\hline
\end{tabular}


Table 2 Summary statistics for scaffolds and predicted genes. Metrics are listed for scaffolds of at least 1 kbp as determined using the quast software

\begin{tabular}{lll}
\hline metric & R. gorgonias & C. arborea \\
\hline Total length $(>=10 \mathrm{kbp})$ & $235,721,577$ & $437,604,713$ \\
Total length $(>=25 \mathrm{kbp})$ & $200,375,750$ & $384,820,916$ \\
Total length $(>=50 \mathrm{kbp})$ & $125,205,191$ & $312,317,250$ \\
\# contigs & 20,623 & 29,265 \\
Largest contig & 191,047 & 616,539 \\
Total length & $284,273,507$ & $511,026,369$ \\
GC (\%) & 36.60 & 38.50 \\
N50 & 46,982 & 67,174 \\
\# N's per 100 kbp & 734.67 & $2,082.52$ \\
Total BUSCO groups searched & 2121 & 2121 \\
Complete BUSCOs & $1787(84.2 \%)$ & $1899(89.5 \%)$ \\
Complete \& single-copy BUSCOs & $1712(80.7 \%)$ & $1744(82.2 \%)$ \\
Complete \& duplicated BUSCOs & $75(3.5 \%)$ & $155(7.3 \%)$ \\
Fragmented BUSCOs & $203(9.6 \%)$ & $135(6.4 \%)$ \\
Missing BUSCOs & $131(6.2 \%)$ & $87(4.1 \%)$
\end{tabular}

BUSCO statistics are based on 2,121 single-copy orthologs of eudicots for the predicted protein sequences of $R$. gorgonias and C. arborea

genome-scale data for other Ericales' genomes and $D$. carota as an outgroup, we generated a phylogenomic data set of OMA groups that correspond to 1:1 orthologs. We evaluated the representation of each of the 10 ingroup species in the selected OMA groups. Species for which a genome assembly was available were missing from $1 \%$ (Actinidia chinensis) to $10 \%$ (Primula vulgaris) of the groups. The three transcriptome assemblies, however, showed a considerably higher level of missingness between 64\% (Vaccinium macrocarpon) and 82\% (Sarracenia purpurea). We observed 121 distinct patterns of species absence and presence. The most frequently observed pattern, found in 2,434 of the selected 4,901 OMA groups, contained representatives from all the genomes and none of the transcriptomes.

Although the selected species span large evolutionary distances, and lineage-specific loss or divergence is expected to occur in some gene families, the dramatic difference in absences points to a systematic bias of transcriptomes. RNA-Seq data corresponds to transcripts that are expressed only in a given tissue at a given time, and not all protein-coding genes are therefore represented in a transcriptome assembly. In addition, sequencing errors, alternative splice forms, and paralogs present serious challenges for the assembly of transcriptomes, often resulting in unrealistically large numbers of small transcripts. To reduce this number, different filtering strategies are commonly applied, such as removing lowly expressed transcripts or collapsing transcripts based on sequence identity. The resulting number of transcripts frequently is much closer to the expected number of the organism's (expressed) genes. However, problems remain, since many challenges of transcriptome assemblies cannot be overcome using a post-assembly filtering approach: Most transcripts still are just gene fragments, and, moreover, bona fide genes are frequently filtered out [32]. This was also observed here, with much longer predicted genes from genome data than from transcriptome data (Table 1), and with most of the sets of orthologs missing in species represented by a transcriptome assembly.

Despite the reduced number of species in our final phylogenomic data set, we used it to infer organismal relationships within the Ericales. The 2,434 computed phylogenies revealed 118 different tree topologies, 90 of which were observed fewer than 10 times. The three most frequently observed topologies together accounted for $50 \%$ of the trees; these differ only with respect to the placement of Camellia sinensis and are shown in Figure 1. More genome-based data that include all lineages within the plant order Ericales are needed to confidently resolve their relationships in the future.

\section{Limitations}

In summary, we present annotated genomes of the carnivorous plant $R$. gorgonias and the non-carnivorous relative $C$. arborea. The lengths and numbers of their predicted genes fall entirely within the range of other genome-based data and can be used to study shared and unique adaptations of plant carnivory at the molecular
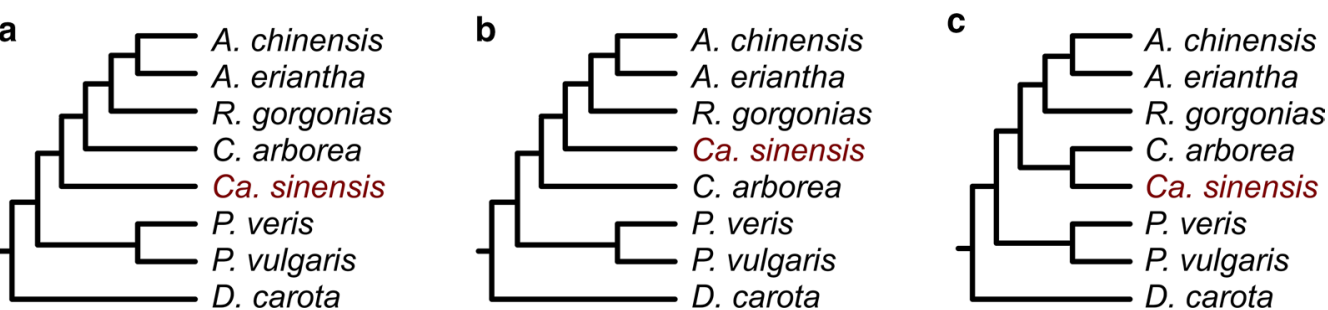

Fig. 1 The most frequently observed ML topologies. Of 2,434 selected OMA families, 814, 218, and 176 trees resulted in the topologies shown in A, $B$, and $C$, respectively 
level. Once additional genomes, rather than transcriptomes, of other carnivorous and non-carnivorous plants within the Ericales are available, the evolution of the different carnivorous adaptations and the relationship of major lineages in this group can be resolved. Limitations of our data set are those inherent in any draft genome: due to the fragmented nature of the assembly, some genes at the end of scaffolds are likely incomplete, scaffolds corresponding to organellar genomic regions might be contained within the assembly, and repeat regions might be missing or misassembled.

\begin{abstract}
Abbreviations
BUSCO: Benchmarking Universal Single-Copy Orthologs; DNA: Deoxyribonucleic acid; HMMs: Hidden Markov Models; IPEN: International Plant Exchange Network; kbp: Kilo base pair; M: Million; Mbp: Mega base pair; NCBI: National Center for Biotechnology Information; nm: Nano meter; RNA: Ribonucleic acid; OMA: Ortholog Matrix Project.
\end{abstract}

\section{Acknowledgements}

We would like to thank the Botanical Garden in Berlin for providing the plant material used in this study, and Alice Dennis for helpful discussions throughout this project.

\section{Authors' contributions}

MP and AS performed the flow cytometry. MP and SA did all molecular lab work. $\mathrm{MH}$ and $\mathrm{SH}$ conceived the study. SH analyzed the data and wrote the manuscript. All authors read and approved the final manuscript.

\section{Funding}

Open Access funding provided by Projekt DEAL. .

\section{Availability of data and materials}

Raw sequence data have been deposited in the Short Read Archive under BioProject ID PRJNA630565 (https://www.ncbi.nlm.nih.gov/sra/?term=PRJNA 630565), with accession numbers SAMN14840030 (R. gorgonias) and SAMN14840031 (C. arborea). Genome assemblies and predicted proteins have been made available at DataDryad under the URL https://doi.org/10.5061/ dryad.573n5tb4k.

\section{Competing interests}

The authors declare that they have no competing interests.

\section{Ethics approval and consent to participate}

Not applicable

\section{Consent to publish}

Not applicable

\section{Author details}

${ }^{1}$ Institute for Biochemistry and Biology, University of Potsdam, Karl-Liebknecht-Str. 24-25, 14476 Potsdam, Germany. ${ }^{2}$ Max-Planck-Institute of Molecular Plant Physiology, Am Mühlenberg 1, 14476 Potsdam, Germany.

Received: 15 May 2020 Accepted: 24 Auqust 2020

Published online: 10 September 2020

\section{References}

1. Ellison AM, Gotelli NJ. Energetics and the evolution of carnivorous plantsdarwin's 'most wonderful plants in the world'. J Exp Bot. 2009;60(1):19-42. https://doi.org/10.1093/jxb/ern179.

2. Ibarra-Laclette E, Lyons E, Hernández-Guzmán G, Pérez-Torres CA, Carretero-Paulet L, Chang T-H, Lan T, Welch AJ, Juárez MJA, Simpson J, Fernández-Cortés A, Arteaga-Vázquez M, Góngora-Castillo E,
Acevedo-Hernández G, Schuster SC, Himmelbauer H, Minoche AE, Xu S, Lynch M, Oropeza-Aburto A, Cervantes-Pérez SA, de Jesús Ortega-Estrada M, Cervantes-Luevano Jl, Michael TP, Mockler T, Bryant D, Herrera-Estrella A, Albert VA, Herrera-Estrella L. Architecture and evolution of a minute plant genome. Nature. 2013;498(7452):94-8. https://doi.org/10.1038/ nature12132.

3. Leushkin EV, Sutormin RA, Nabieva ER, Penin AA, Kondrashov AS, Logacheva MD. The miniature genome of a carnivorous plant genlisea aurea contains a low number of genes and short non-coding sequences. BMC Genomics. 2013;14:476. https://doi.org/10.1186/1471-2164-14-476.

4. Silva SR, Moraes AP, Penha HA, Julião MHM, Domingues DS, Michael TP, Miranda VFO, Varani AM. The terrestrial carnivorous plant utricularia reniformis sheds light on environmental and life-form genome plasticity. Int J Mol Sci. 2019;21:1. https://doi.org/10.3390/ijms21010003.

5. Fukushima K, Fang X, Alvarez-Ponce D, Cai H, Carretero-Paulet L, Chen C, Chang T-H, Farr KM, Fujita T, Hiwatashi Y, et al. Genome of the pitcher plant cephalotus reveals genetic changes associated with carnivory. Nat Ecol Evol. 2017:1:0059.

6. Butts CT, Bierma JC, Martin RW. Novel proteases from the genome of the carnivorous plant drosera capensis: Structural prediction and comparative analysis. Proteins. 2016;84(10):1517-33. https://doi.org/10.1002/ prot.25095.

7. Srivastava A, Rogers WL, Breton CM, Cai L, Malmberg RL. Transcriptome analysis of sarracenia, an insectivorous plant. DNA Res. 2011;18(4):253-61. https://doi.org/10.1093/dnares/dsr014.

8. Jensen MK, Vogt JK, Bressendorff S, Seguin-Orlando A, Petersen M, Sicheritz-Pontén T, Mundy J. Transcriptome and genome size analysis of the venus flytrap. PLoS ONE. 2015;10(4):0123887. https://doi.org/10.1371/ journal.pone.0123887.

9. Bárta J, Stone JD, Pech J, Sirová D, Adamec L, Campbell MA, Štorchová H. The transcriptome of utricularia vulgaris, a rootless plant with minimalist genome, reveals extreme alternative splicing and only moderate sequence similarity with utricularia gibba. BMC Plant Biol. 2015;15:78. https://doi.org/10.1186/s12870-015-0467-8.

10. Ibarra-Laclette E, Albert VA, Pérez-Torres CA, Zamudio-Hernández F, Ortega-Estrada MdJ, Herrera-Estrella A, Herrera-Estrella L. Transcriptomics and molecular evolutionary rate analysis of the bladderwort (utricularia), a carnivorous plant with a minimal genome. BMC Plant Biol. 2011;11:101. https://doi.org/10.1186/1471-2229-11-101.

11. Voigt $D$, Gorb S. Desiccation resistance of adhesive secretion in the protocarnivorous plant roridula gorgonias as an adaptation to periodically dry environment. Planta. 2010;232(6):1511-5. https://doi.org/10.1007/s0042 5-010-1270-2.

12. Bennett MD, Leitch IJ. Nuclear dna amounts in angiosperms: progress, problems and prospects. Ann Bot. 2005;95(1):45-90. https://doi. org/10.1093/aob/mci003.

13. Hayden WJ. There's much left to learn: Clethra's chromosomes. Sempervirens. 2015;4:

14. Otto F. Dapi staining of fixed cells for high-resolution flow cytometry of nuclear dna. Methods Cell Biol. 1990;33:105-10.

15. Altschul SF, Gish W, Miller W, Myers EW, Lipman DJ. Basic local alignment search tool. J Mol Biol. 1990;215(3):403-10. https://doi.org/10.1016/50022 $-2836(05) 80360-2$.

16. Camacho C, Coulouris G, Avagyan V, Ma N, Papadopoulos J, Bealer K, Madden TL. Blast+: architecture and applications. BMC Bioinform. 2009;10:421. https://doi.org/10.1186/1471-2105-10-421.

17. Huson DH, Albrecht B, Bağcı C, Bessarab I, Górska A, Jolic D, Williams RBH. Megan-Ir: new algorithms allow accurate binning and easy interactive exploration of metagenomic long reads and contigs. Biol Direct. 2018;13(1):6. https://doi.org/10.1186/s13062-018-0208-7.

18. Holt C, Yandell M. Maker2: an annotation pipeline and genome-database management tool for second-generation genome projects. BMC Bioinform. 2011;12:491. https://doi.org/10.1186/1471-2105-12-491.

19. Pilkington SM, Crowhurst R, Hilario E, Nardozza S, Fraser L, Peng Y, Gunaseelan K, Simpson R, Tahir J, Deroles SC, Templeton K, Luo Z, Davy M, Cheng C, McNeilage M, Scaglione D, Liu Y, Zhang Q, Datson P, De Silva N, Gardiner SE, Bassett H, Chagné D, McCallum J, Dzierzon H, Deng C, Wang Y-Y, Barron L, Manako K, Bowen J, Foster TM, Erridge ZA, Tiffin H, Waite CN, Davies KM, Grierson EP, Laing WA, Kirk R, Chen X, Wood M, Montefiori M, Brummell DA, Schwinn KE, Catanach A, Fullerton C, Li D, Meiyalaghan S, Nieuwenhuizen N, Read N, Prakash R, Hunter D, Zhang H, McKenzie 
M, Knäbel M, Harris A, Allan AC, Gleave A, Chen A, Janssen BJ, Plunkett B, Ampomah-Dwamena C, Voogd C, Leif D, Lafferty D, Souleyre EJF, Varkonyi-Gasic E, Gambi F, Hanley J, Yao J-L, Cheung J, David KM, Warren B, Marsh K, Snowden KC, Lin-Wang K, Brian L, Martinez-Sanchez M, Wang M, lleperuma N, Macnee N, Campin R, McAtee P, Drummond RSM, Espley RV, Ireland HS, Wu R, Atkinson RG, Karunairetnam S, Bulley S, Chunkath S, Hanley Z, Storey R, Thrimawithana AH, Thomson S, David C, Testolin R, Huang H, Hellens RP, Schaffer RJ. A manually annotated actinidia chinensis var. chinensis (kiwifruit) genome highlights the challenges associated with draft genomes and gene prediction in plants. BMC Genomics. 2018;19(1):257. https://doi.org/10.1186/s12864-018-4656-3.

20. Tang W, Sun X, Yue J, Tang X, Jiao C, Yang Y, Niu X, Miao M, Zhang D, Huang S, Shi W, Li M, Fang C, Fei Z, Liu Y. Chromosome-scale genome assembly of kiwifruit actinidia eriantha with single-molecule sequencing and chromatin interaction mapping. Gigascience. 2019;8:4. https://doi. org/10.1093/gigascience/giz027.

21. UniProt Consortium. Uniprot: a worldwide hub of protein knowledge. Nucleic Acids Res. 2019;47(D1):506-15. https://doi.org/10.1093/nar/gky10 49.

22. Train C-M, Glover NM, Gonnet GH, Altenhoff AM, Dessimoz C. Orthologous matrix (oma) algorithm 2.0: more robust to asymmetric evolutionary rates and more scalable hierarchical orthologous group inference. Bioinformatics. 2017;33(14):75-82. https://doi.org/10.1093/bioinforma tics/bt×229.

23. Haas BJ, Papanicolaou A, Yassour M, Grabherr M, Blood PD, Bowden J, Couger MB, Eccles D, Li B, Lieber M, MacManes MD, Ott M, Orvis J, Pochet N, Strozzi F, Weeks N, Westerman R, William T, Dewey CN, Henschel R, LeDuc RD, Friedman N, Regev A. De novo transcript sequence reconstruction from rna-seq using the trinity platform for reference generation and analysis. Nat Protoc. 2013;8(8):1494-512. https://doi.org/10.1038/ nprot.2013.084

24. Khayi S, Azza N, Gaboun F, Pirro S, Badad O, Claros M, Lightfoot D, Unver T, Chaouni B, Merrouch R, Rahim B, Essayeh S, Ganoudi M, Abdelwahd R, Diria G, Mdarhi M, Labhilili M, Iraqi D, Mouhaddab J, Sedrati H, Memari M, Hamamouch N, Alché J, Boukhatem N, Mrabet R, Dahan R, Legssyer A, Khalfaoui M, Badraoui M, Van de Peer Y, Tatusova T, El Mousadik A, Mentag $\mathrm{R}$, Ghazal $\mathrm{H}$. First draft genome assembly of the argane tree (argania spinosa) [version 1; peer review: 1 approved, 1 approved with reservations]. F1000Research. 2018;7(1310). https://doi.org/10.12688/f1000resea rch.15719.1

25. Beletsky AV, Filyushin MA, Gruzdev EV, Mazur AM, Prokhortchouk EB, Kochieva EZ, Mardanov AV, Ravin NV, Skryabin KG. De novo transcriptome assembly of the mycoheterotrophic plant monotropa hypopitys. Genom Data. 2017;11:60-1. https://doi.org/10.1016/j.gdata.2016.11.020.

26. Iorizzo M, Ellison S, Senalik D, Zeng P, Satapoomin P, Huang J, Bowman M, lovene M, Sanseverino W, Cavagnaro P, Yildiz M, Macko-Podgórni A, Moranska E, Grzebelus E, Grzebelus D, Ashrafi H, Zheng Z, Cheng S, Spooner D, Van Deynze A, Simon P. A high-quality carrot genome assembly provides new insights into carotenoid accumulation and asterid genome evolution. Nat Genet. 2016;48(6):657-66. https://doi. org/10.1038/ng.3565.
27. Altenhoff AM, Levy J, Zarowiecki M, Tomiczek B, Warwick Vesztrocy A, Dalquen DA, Müller S, Telford MJ, Glover NM, Dylus D, Dessimoz C. Oma standalone: orthology inference among public and custom genomes and transcriptomes. Genome Res. 2019;29(7):1152-63. https://doi. org/10.1101/gr.243212.118.

28. Katoh K, Standley DM. Mafft multiple sequence alignment software version 7: improvements in performance and usability. Mol Biol Evol. 2013;30(4):772-80. https://doi.org/10.1093/molbev/mst010.

29. Stamatakis A. Raxml version 8: a tool for phylogenetic analysis and postanalysis of large phylogenies. Bioinformatics. 2014;30(9):1312-3. https:// doi.org/10.1093/bioinformatics/btu033.

30. Gurevich A, Saveliev V, Vyahhi N, Tesler G. Quast: quality assessment tool for genome assemblies. Bioinformatics. 2013;29(8):1072-5. https://doi. org/10.1093/bioinformatics/btt086.

31. Simão FA, Waterhouse RM, loannidis P, Kriventseva EV, Zdobnov EM. Busco: assessing genome assembly and annotation completeness with single-copy orthologs. Bioinformatics. 2015;31(19):3210-2. https://doi. org/10.1093/bioinformatics/btv351.

32. Freedman AH, Clamp M, Sackton TB. Error, noise and bias in de novo transcriptome assemblies. bioRxiv, 585745, 2019.

33. Wei C, Yang H, Wang S, Zhao J, Liu C, Gao L, Xia E, Lu Y, Tai Y, She G, Sun J, Cao H, Tong W, Gao Q, Li Y, Deng W, Jiang X, Wang W, Chen Q, Zhang S, Li H, Wu J, Wang P, Li P, Shi C, Zheng F, Jian J, Huang B, Shan D, Shi M, Fang C, Yue Y, Li F, Li D, Wei S, Han B, Jiang C, Yin Y, Xia T, Zhang Z, Bennetzen JL, Zhao $S$, Wan $X$. Draft genome sequence of camellia sinensis var. sinensis provides insights into the evolution of the tea genome and tea quality. Proc Natl Acad Sci USA. 2018;115(18):4151-8. https://doi.org/10.1073/ pnas. 1719622115.

34. Nowak MD, Russo G, Schlapbach R, Huu CN, Lenhard M, Conti E. The draft genome of primula veris yields insights into the molecular basis of heterostyly. Genome Biol. 2015;16:12. https://doi.org/10.1186/s1305 9-014-0567-z.

35. Cocker JM, Wright J, Li J, Swarbreck D, Dyer S, Caccamo M, Gilmartin PM. Primula vulgaris (primrose) genome assembly, annotation and gene expression, with comparative genomics on the heterostyly supergene. Sci Rep. 2018;8(1):17942. https://doi.org/10.1038/s41598-018-36304-4.

36. Polashock J, Zelzion E, Fajardo D, Zalapa J, Georgi L, Bhattacharya D, Vorsa $\mathrm{N}$. The american cranberry: first insights into the whole genome of a species adapted to bog habitat. BMC Plant Biol. 2014;14:165. https://doi. org/10.1186/1471-2229-14-165.

37. Akagi T, Henry IM, Tao R, Comai L. Plant genetics. a y-chromosomeencoded small rna acts as a sex determinant in persimmons. Science. 2014;346(6209):646-50. https://doi.org/10.1126/science.1257225.

\section{Publisher's Note}

Springer Nature remains neutral with regard to jurisdictional claims in published maps and institutional affiliations.

\footnotetext{
Ready to submit your research? Choose BMC and benefit from:

- fast, convenient online submission

- thorough peer review by experienced researchers in your field

- rapid publication on acceptance

- support for research data, including large and complex data types

- gold Open Access which fosters wider collaboration and increased citations

- maximum visibility for your research: over 100M website views per year
}

At BMC, research is always in progress.

Learn more biomedcentral.com/submissions 